\title{
ULTRASTRUCTURE OF SECRETORY ALVEOLI OF LACTATING MAMMARY GLAND OF ONE HUMPED SHE-CAMEL (CAMELUS DROMEDARIES)
}

\author{
El-Habback H. A.
}

Department of Cytology \& Histology, Faculty of Veterinary Medicine, Cairo University.

\section{ABSTRACT}

Ultrastructure of the secretory alveoli of the one humped she camel was performed during lactation. The alveolar epithelium was cuboidal represented by four cell types. These epithelial cells exhibited marked change in cellular height, distinct variations of shape, size and location of their nuclei and a progressive development of their organelles during lactation. The most characteristic feature was the presence of deep basal folding of the epithelium and the distribution of the mitochondria giving the model of ion transporting cell. The relationship between the fine structure and the nutritional contribution made by camel milk as well as the mode of lipid and protein secretion was discussed.

\section{INTRODUCTION}

Anti-infection, anti-cancer, anti-diabetes: these were bold claims to make about any substance, but scientific and commercial interest was growing in such claims that have long been made about the milk of camels. Camels were kept in over a hundred countries, there were traditional sayings or practices in which the alleged healing properties of camel milk and milk products were shared and passed from generation to generation. These properties of camel milk provided a bright future for camel dairying (Baker et al., 2002). 
There was comparatively little information on the fine structure of the she-camel mammary gland during lactation. Ultrastructural studies have been made by Brooker (1984) in ewe, Nickerson et al., (1982), Dylewski et al., (1984), and Ludewig (1996) in bovine, Welsch et al., (1998) in elephant, Sekhri \& Faulkin (1970), Pulley (1973), Bomhard \& Kappes (1976) and Sinowatz et al., (1980) in canine and Franke \& Keenan (1979). On the other hand, El-Kholy (1994) mentioned the light microscope of postnatal development of mammary gland of she- camel while Moussa et al. (1981) described the contractile tissue of mammary gland of the same species.

The aim of the present investigation was to give a more detailed description on the ultrastructural of the mammary gland of she- camel during lactation and shed more attention on the relationship between the fine structure and the nutritional contribution made by camel milk.

\section{MATERIAL \& METHODS}

The lactating mammary glands of 6 adult she- camels (6-8 years old) were collected from Cairo slaughter house after taking their data and history from the owners. For TEM, $1.0 \mathrm{~mm} 3$ samples of the glandular tissue of each udder were cut. The tissue was immersed in 5.0\% glutaraldehyde buffered at PH 7.2-7.4 with $0.1 \mathrm{M}$ sodium cacodylate. After fixation, specimens were rinsed in the buffer, and immersed in $1.0 \%$ osmium tetroxide in $0.1 \mathrm{M}$ cacodylate at the same $\mathrm{PH}$. The tissues were then dehydrated, cleared in propylene oxide, and embedded in epon resin (Hayat, 1989). "Thick" survey sections (1.0 to $1.5 \mathrm{Nm}$ ) were cut with a glass knife, and stained with toluidine blue for light microscopy. Ultrathin sections were cut with a diamond knife, stained with uranyl acetate and lead citrate and examined using Jeol TEM 100 CX II at $80 \mathrm{Kv}$. 


\section{RESULTS}

The structural unit of the lactating mammary gland of one humped camel mainly consisted of lobules. These lobules were populated by many irregular secretory alveoli and duct systems (Fig. 1). An alveolus was composed of a single layer of cuboidal epithelial cells surrounding a lumen, rest on basement membrane, and surrounded by a basket network of myoepithelial cells (Figs. $2 \& 3$ ). The myoepithelial cells formed a discontinuous stratum around the alveoli. Blood vessels and capillaries run through the stroma (inter-alveolar space). This intralobular connective tissue had also fibrocytes, plasma cells, single lymphocyte, fine collagen fibers and numerous blood cells (Figs. $2 \& 3$ ). Infiltration of small lymphocytes inbetween the epithelium has been observed.

Ultrastructural investigation of the secretory alveoli of the lactating mammary gland revealed several types of cells:

\section{Type I cell:}

It was low cuboidal. The luminal face of the cells bore sporadic short microvilli (Fig. 4). The nuclei were large and elongated, some of them showed a degree of indentation. A narrow rim of heterochromatin was seen lining the inner nuclear membrane (Figs. 4 \& 5). Furthermore, the glandular epithelial cytoplasm was marked by numerous free ribosomes, several cisternae of rough endoplasmic reticulum $(\mathrm{rER})$, small mitochondria, a medium-sized supranuclear Golgi apparatus and occasionally myelin figures (Fig. 4). Vesicles containing electron dense granules were few and noticed near to the apical membrane (Figs. 4 \& 5). The lumen contained few electron dense secretory granules (Figs. 4 \& 5). The myoepithelial cells were clearly discernible and extended their cytoplasmic processes around the glandular epithelium where the basal cell membrane was smooth (Fig. 5). Intra and interepithelial lymphocytes were detected (Fig. 5). 


\section{Type II cell:}

The height of the glandular epithelium was reduced (as compared to previous cell type); the nuclei appeared irregularly shaped and more heterochromatic with clear nucleolus (Figs. 6 \& 7). The cytoplasm had slightly dilated rER than that of type 1 cells and rod shaped mitochondria that evenly distributed through the apical cytoplasm. Golgi complex more dilated and occupied supra-nuclear region (Fig. 7). The basal cell memebrane very often forms densely spaced microfolds where the mitochondria were concentrated toward these folds (Fig. 6). These folds were rested on apparent basement membrane. Vesicles containing electron dense granules were comparatively increased and became near to the apical membrane (Fig. 7). Myoepithelial cells were completely surrounded the glandular epithelium except where basal infolding appeared (Figs. $6 \&$ 8). The lumen of the glandular epithelium showed more electron dense granules (Fig. 7).

\section{Type III cells:}

The alveoli were dilated by a large amount of the secretory material which distended their lumina. The apical parts of the glandular cells were dome-shaped and protruded into the alveolar lumen (Fig. 9). The epithelial height was quietly reduced. Very few short microvilli were occasionally seen at the apical plasma membrane (Fig. 11). The nuclei of the glandular cells were round to oval with a marginal zone of dense chromatin. Many of them showed pronounced nucleoli. Many electron lucent lipid droplets of varying sizes occupied a large part of the cytoplasm and form bleb like (Fig. 9). Usually the cisternae of the endoplasmic reticulum formed evenly distributed arrays and many ribosomes were attached to the cisternae (Fig. 11). Golgi apparatus was well developed. There were many mitochondria which were usually found scattered in the cytoplasm, but occasionally a greater number were $\overline{\text { Kafrelsheikh Vet. Med. J. Vol. } 5 \text { No. } 2 \text { (2007) }}$ 
seen in clustered at the basal region of the cells near to the basal infolding (Figs $12 \& 13$ ). In some cells mitochondria were sometimes seen aligned along the lateral plasma membrane with variable amounts of intervening cytoplasm (Fig. 10). High proportion of the mitochondria was detected to be long and slender, and some were seen with a markedly attenuated middle segment and 2 sacculated. U- and ringshaped mitochondria were also frequently seen, and the cytoplasm located within the confines of their concave surfaces was much less dense than the surrounding cytoplasm (Figs. 10 \& 13 \& 15 ). Mitochondria with a lattice structure within one or two cristae were occasionally seen. Such structures were usually in the narrower parts of a mitochondrion and appear to constrain the mitochondrial shape (Fig. 13).

A very striking feature in the secretory epithelium was the frequent occurrence of mitochondria with an apparently specific association with the tonofilament-desmosomal complex. Desmosomes were present in most lactating cells just below the tight junctions (Figs. 10 \& 11). In some sections through the epithelium just below the tight junction all the desmosomes have mitochondria in close association. Desmosomes lower down the lateral surface showed less frequently. A desmosome may have mitochondria associated with both ends in contiguous cells (Figs. 10 \& 11). Desmosomes with a mitochondrion on only one side were less frequent (Fig. 10).

Several membrane-bounded large (organelles with heterogeneous contents; these were apparently lysosomes) and regularly displayed myelin figures or comparable stacks of membranous material were unfortunately found (Fig. 9). Blood capillaries lined by continous endothelial cells were observed in interalveolar connective tissues (Fig. 9), their endothelium showed pinocytotic activities (Fig. 14). 


\section{Type IV cells:}

The glandular epithelium was much reduced. Ultrastructure of the alveolar epithelium revealed abundant rough endoplasmic reticulum consisted of well developed cisternae filled with a moderately electrondense material. Usually the cisternae of the endoplasmic reticulum were arranged in parallel arrays and with many ribosomes (Figs. $14 \& 15$ ). The Golgi apparatus was well developed and varying numbers of mitochondria were evenly dispersed throughout the cytoplasm (Fig. 15). The nuclei of the secretory cells were round to oval with peripheral dense chromatin. Many of them showed pronounced indentation (Fig. 14). In the apical cytoplasm, electron-lucent lipid droplets were seen to be elaborated with the apical cytoplasm into the lumen (Figs. $2 \& 3 \& 14$ ). On the other hand; the vesicles containing electron dense granules began to join each other to form large one. Furthermore, the latter joined to the apical membrane and evacuated their contents into the lumen. The apical plasma membrane exhibited individual short microvilli (Fig. 14).

The myoepithelial cells appeared distended and flat; their morphology did not depend on the stage of secretory activity (Fig. 15). However, when a secretory cell was in direct contact with the basal lamina, its basal surface was thrown into deep folds but that where a myoepithelial cell was interposed, the cell membrane was smooth (Figs. $14 \& 15)$.

\section{DISCUSSION}

This investigation shows that the glandular parenchyma of one humped she-camel consisted of a luminal layer of secretory cells and surrounded by contractile myoepithelial cells. These were in many respects similar to that described for other mammals such as the rat (Bargmann \& Knoop, 1959; Cowie \& Tindal, 1971; Helminen \& Ericsson, 1968 and Radnor, 1972), mouse (Hollmann, 1959 and

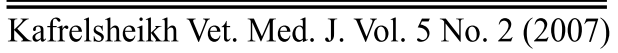


Bargmann et al., 1961), pig (Adamiker \& Glawischnig, 1967a, b), cow (Feldmann, 1961) and man (Waugh \& van der Hoeven, 1962; Toker, 1967; Murad \& v. Haam, 1968; Gros \& Girardie, 1970 and Stirling \& Chandler, 1976) and she-camel Moussa et al. (1981) and (EL-Kholy, 1994).

In our study, during Lactation the secretory epithelial cells of one humped camel exhibit a marked change in cellular height, distinct variations of shape, size and location of their nuclei and a progressive development of the rough endoplasmic reticulum and Golgi apparatus. This fact was true in different animal species bovine (Brook, 1983), ewe (Brooker, 1984) and rat (Franke \& Keenan, 1979).

The most characteristic feature of the epithelial cells of lactating mammary gland of one humped camel was the distribution of the mitochondria along the lateral membrane, associated to the desmosome and near to the basal infolding. Evidence for margination of the mitochondria of the mammary epithelial cells seemed significant only to transport of some kind between the two cells (Lee et al., 1979). The presence of the mitochondrial population in close association with the tonofilament-desmosomal complex resembled the finding of Pitelka (1978) that in the mouse there were few if any desmosomes left at full lactation; the situation seems very different in the cow, since even late in lactation desmosomes of conventional structure were usually present. A large number of these desmosomes have mitochondria alongside, but the mitochondria were most closely associated with the tonofilaments that run into the desmosomal plaque. No continuity between the attached tonofilaments and the mitochondrial outer membrane has been clearly demonstrated. However, the uniformity of the separation between tonofilament and mitochondrion suggests there may be specific adhesion (Lee et al., 1979). 
It was possible that the mitochondria were associated more directly with tonofilaments originating from the desmosomal plaque than with the plaque itself. Initial suggestions that the association was peculiar to foetal, neonatal or developing epithelia (Deane et al., 1966). Since Pitelka (1978) has indicated that desmosomes do decrease in number at the onset of lactation in the mouse and rabbit it was possible that the association with mitochondria observed in the cow was related to changes in tonofilament and/or desmosomal distribution. However, we could find no indication of any decrease in individual tonofilament and desmosomal substance or frequency whatever the stage of lactation.

Since the mitochondria seem to be closer to the tonofilaments than the desmosomal plaque material it could be that the association represents a purely fortuitous bottleneck in the cellular transport system. The later could be involved in a continuous traffic of lipid droplets from the basal regions of the cell where they form, and of Golgi vesicles from the Golgi body, to the apical plasmalemma where they were continuously released (Lee et al., 1979).

Tonofilaments (or intermediate filaments) have been implicated in intracellular movements in cultured cells (Goldman, 1971). If mitochondria moved along filament surfaces they would be expected to stop when the filament inserts into the desmosomal plaque. In the mammary secretory cell cytoplasm tonofilaments usually run singly and no unequivocal association with the mitochondrial outer membrane has been observed. When tonofilaments group into small bundles near the lateral plasmalemma, mitochondria were occasionally seen in association with these bundles away from any desmosomal plaque. This might enable the filaments to play a more active role in organellar movement as well as their more conventional structural or 'guy rope' function (Lee et al., 1979) and our study. 
A morphological correlation of the unusually well-developed basal membrane folds in the actively lactating glandular cells together with abundant mitochondria could suggest considerable fluid and electrolyte transportation across the basal membrane of the lactating active cells in elephant (Welsch et al., 1998) and she-camel.

The arrangement of mitochndria and the deep basal infolding could represent the module design of ion transporting cell in lactating mammary gland of one humped camel as the concentration of lactophorin in camel milk was found to be about three times higher than the concentration of the bovine homologue in bovine milk (Kappeler et al., 1999). This might compensate the great demand of iron (essential fraction of lactophorin) traffic across the basal folding of lactating cell in this study. Lactophorin enhanced the immune response, both directly and indirectly (passively,) in reaction to a wide range of immune challenges, and was an essential factor in the immune response in humans (Baker et al. 2002).

In the present study, these deep basal folding together with the endothelium of the capillaries in perialveolar connective tissue contains many pinocytotic vesicles and the myoepithelial cells could share in the formation remarkable structures in the blood-milk-barrier that was described in cow (Ludewig, 1996). This barrier gave credence to the model's potential value for determining antibiotic diffusion from milk to blood and from blood to milk, cytotoxicity of prophylactic and therapeutic mammary infusion products, factors affecting bacterial adhesion and penetration of mammary epithelial tissue as well as effectiveness of antibodies present in lacteal secretions in preventing bacterial adhesion (Guidry et al., 1998) in bovine. 
The secretory mechanism in the glandular epithelium of the one humped camel mammary gland was basically the same as in other species. Lipid droplets were usually sequestered by apocrine extrusion. Occasionally, lipid droplets were pinched off together with some cytoplasmic material (Bousquet, 2002). Apocrine mode of secretion for lipid was confirmed by the presence of large numbers of cell fragments in camel's milk including mitochondria and abundant rough endoplasmic reticulum (Abdurahman et al. 1992).

On the other hand, the electron dense granules within the vesicles were extruded by reversed pinocytosis. These electron dense granules were defined as Proteins by (Bousquet, 2002). He added that protein carried through membrane compartments were released in the lumen after fusion of secretory vesicles with the apical membrane. These processes assure a relatively constant composition of milk but it was not known whether lipid and protein secretion were linked. The protein composition of the milk fat globule membrane and the stimulatory effects of prolactin and oxytocin on lipid and protein secretion suggest that these processes were coupled and co-regulated.

The occurrence of lymphocytes and other leucocytes in the secretory epithelium of lactating mammals was well established (Helminen \& Ericsson, 1968 and Seelig \& Beer, 1978) but there were few reports of their occurrence in the epithelium of large ducts and of the sinuses. Their true significance was not known but in the case of lymphocytes it has been suggested that they originate from the gut, enter the lumen of the gland (Seelig \& Beer, 1978) and have a protective role to play when colostrum or milk was ingested by the immunologically immature suckling infant (Parmely \& Beer, 1977). The presence of great amount of plasma cells in interalveolar connective tissues in the lactating mammary gland of one humped camel could explained the medical sector of the immunoglobulin of camel milk that contributes to immunity against infection (Abdurahman, 2006). 


\section{LIST OF FIGURES}

Fig. (1): Ultrathin section in one lobule of the lactating mammary gland of shecamel showing many irregular secretory alveoli (A) separated by interalveolar C. T. housing blood vessels (B). Toulidine blue stain, X 410 .

Fig. (2): Ultrathin section in the lactating mammary gland of she- camel showed the cuboidal lining epithelium (E) of the secretory alveolus. The interalveolar C. T. contained blood vessels (B) and plasma cell (arrow head). Note the myoepithelial cell (M) and lipid droplet (L). Toulidine blue stain, X 1025.

Fig. (3): Ultrathin section in the lactating mammary gland of she- camel revealed that the interalveolar C. T. contained blood vessels (B), plasma cell (large arrows) and lymphocyte (small arrow). Note the myoepithelial cell (arrow head) and protruded lipid droplet (L). Toulidine blue stain, X 1025 .

Fig. (4): Electron micrograph of the secretory alveolus of lactating mammary gland of she-camel illustrated that type 1 cell had short microvilli (arrow). Notice nucleus (N), rER (R), Mitochondria (m), myelin figures (M) and vesicles contain electron dense granules $(\mathrm{V})$. The lumen revealed electron dense secretory granules (arrow head). Uranyle acetate- Lead citrate, X 3000.

Fig. (5): Electron micrograph of the type 1 cell of the secretory alveolus of lactating mammary gland of she-camel showing the nucleus $(\mathrm{N})$, vesicles contain electron dense granules $(\mathrm{V})$, intra and interepithelial lymphocytes (L). The lumen revealed electron dense secretory granules (arrow head). Notice the cytoplasmic processes (arrows) of the myoepithelial cell (M). Uranyle acetate- Lead citrate, X 2000.

Fig. (6): Electron micrograph of the type 2 cell of the secretory alveolus of lactating mammary gland of she-camel revealed the nucleus $(\mathrm{N}), \mathrm{rER}$ $(\mathrm{R})$, Mitochondria $(\mathrm{m})$, vesicles contain electron dense granules (V) and short microvilli (arrows). The lumen demonstrated electron dense secretory granules (arrow head). Notice the myoepithelial cell (M) and the basal folding (F). Uranyle acetate- Lead citrate, X 4000. 
Fig. (7): High magnification of (figure 6) revealed the nucleus (N), Golgi complex (G), Mitochondria (m), vesicles contain electron dense granules (V) and short microvilli (arrow). The lumen demonstrated electron dense secretory granules (arrow head). Uranyle acetate- Lead citrate, X 9000.

Fig. (8): Electron micrograph of the type 2 cell of the secretory alveolus of lactating mammary gland of she-camel revealed rER (R), ring shaped mitochondria $(\mathrm{m})$, myoepithelial cell $(\mathrm{M})$ and the basal folding $(\mathrm{F})$. Notice the basement membrane (arrow head). Uranyle acetate- Lead citrate, X 18000.

Fig. (9): Electron micrograph of the type 3 cell of the secretory alveolus of lactating mammary gland of she-camel revealed the protruded lipid (L) into the lumen. The cytoplasm had lysosomes (arrows) and myelin figures (arrow head). Notice the myoepithelial cell (M), the basal folding (F). the continuous endothelium (E) lining the interalveolar blood vessels. Uranyle acetate- Lead citrate, X 2000.

Fig. (10): Electron micrograph of two contiguous type 3 cells of the secretory alveolus of lactating mammary gland of she-camel revealed tight junction (arrow), desmosomes (arrow heads) and the distribution of the mitochondria $(\mathrm{m})$ on both sides of desmosomes. Uranyle acetateLead citrate, X 15000 .

Fig. (11): High magnification of (fig. 10) showed the microvilli (curved arrow), tight junction (arrow), desmosomes (arrow heads), $\mathrm{rEr}(\mathrm{R})$ and the the mitochondria $(\mathrm{m})$ on both sides of desmosomes. Uranyle acetate- Lead citrate, X 22000.

Fig. (12): Electron micrograph of the basal part of type 3 cell of the secretory alveolus of lactating mammary gland of she-camel demonstrated the distribution of mitochondria $(\mathrm{m})$, the deep basal folding $(\mathrm{F})$ and the pronounced basement membrane (arrow). Uranyle acetate- Lead citrate, $\mathrm{X} 11000$. 
Fig. (13): Electron micrograph of the basal part of type 3 cell of the secretory alveolus of lactating mammary gland of she-camel demonstrated rER $(\mathrm{R})$, the distribution of mitochondria $(\mathrm{m})$, the deep basal folding $(\mathrm{F})$ and the pronounced basement membrane (arrow). Notice the marked attenuation in the middle segment of the mitochondria (arrow head). Uranyle acetate- Lead citrate, X 13000.

Fig. (14): Electron micrograph of the type 4 cell of the secretory alveolus of lactating mammary gland of she-camel showed the indented nucleus $(\mathrm{N})$, rER (R), Mitochondria (m), vesicles contain electron dense granules (V), short microvilli (small arrow) and Basal folding (F). Notice the elaboration of lipid (L) with apical cytoplasm into the lumen. On the other side the vesicles contain electron dense granules joined the apical membrane (arrow) to evacuate their contents. The blood vessel in the interalveolar C. T. was lined by continuous endothelium that showed pinocytotic activities (arrow head). Uranyle acetate- Lead citrate, X 4000 .

Fig. (15): Electron micrograph of the basal part of type 4 cell of the secretory alveolus of lactating mammary gland of she-camel demonstrated parallel cisternae of rER (R), Golgi saculles (G), ring shaped mitochondria (arrow), myoepithelial cell (M) and the deep basal folding (F). Notice the marked attenuation in the middle segment of the mitochondria (arrow head). Uranyle acetate- Lead citrate, X 15000 . 

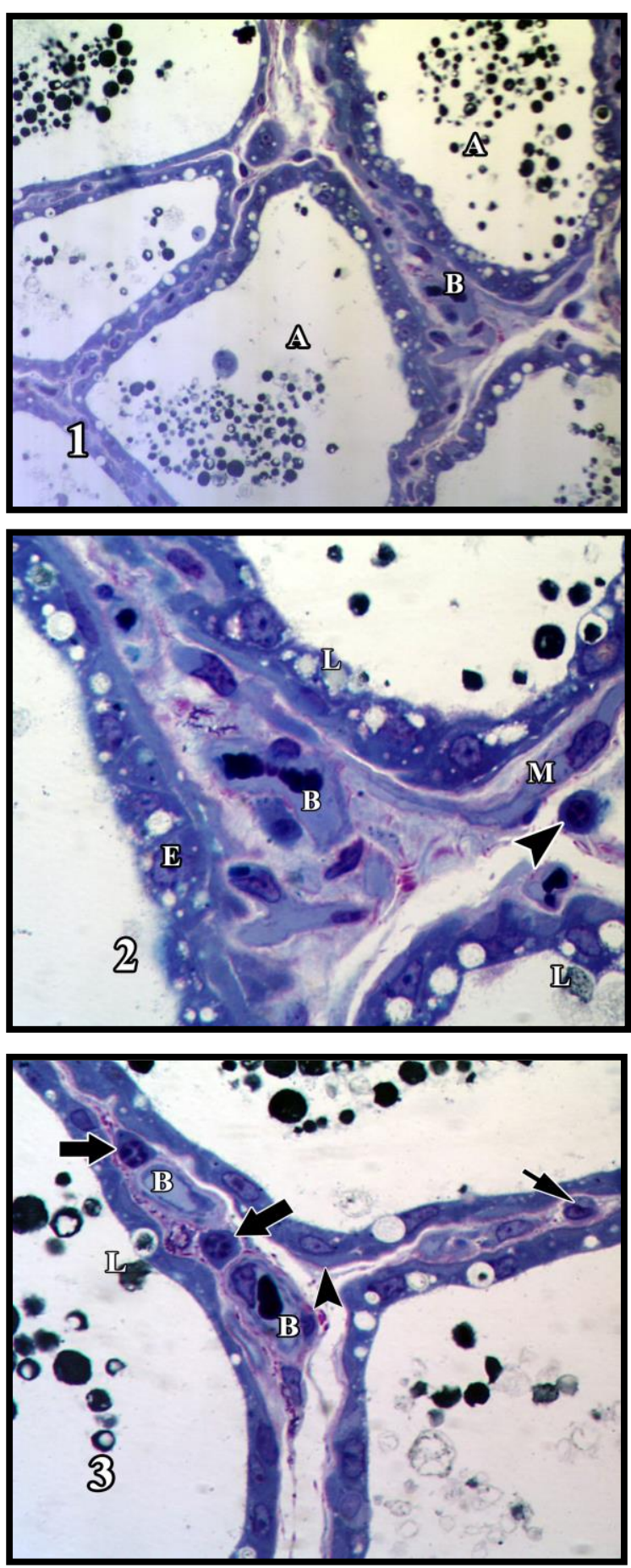

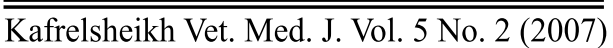



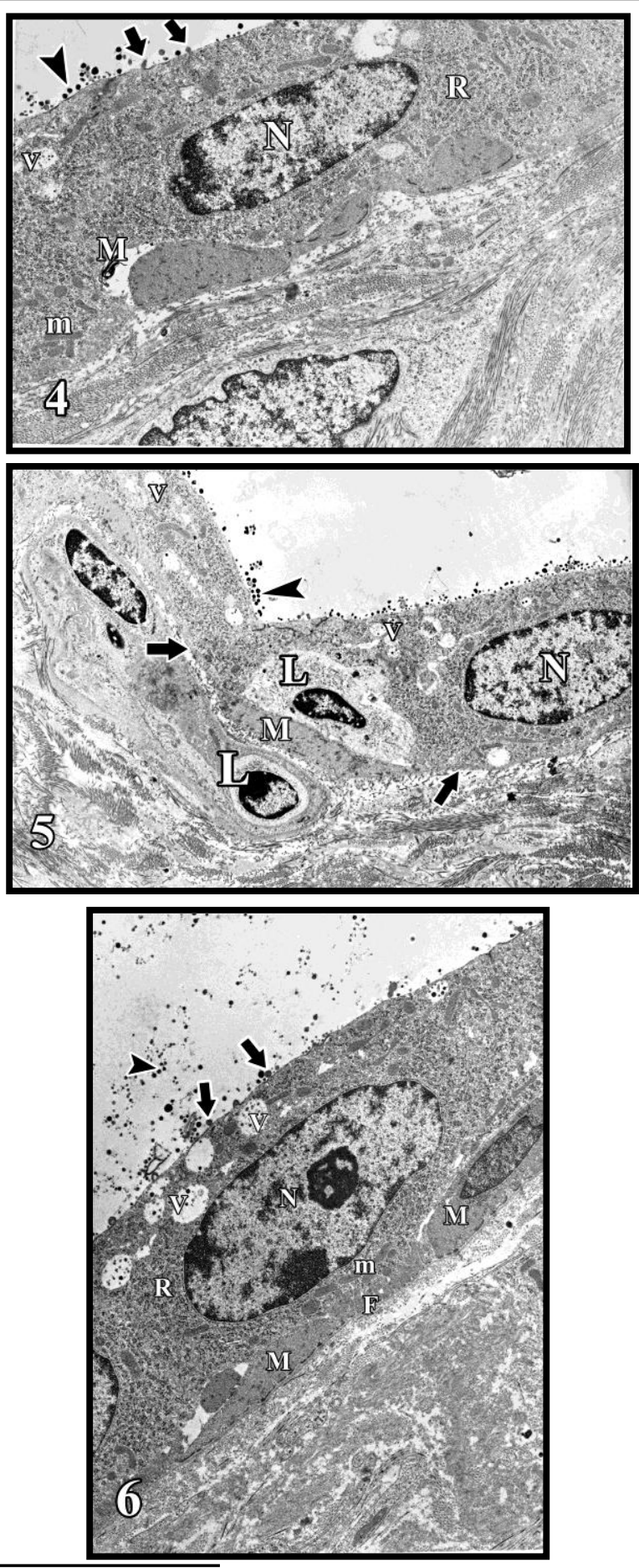

$\overline{\text { Kafrelsheikh Vet. Med. J. Vol. } 5 \text { No. } 2 \text { (2007) }}$ 


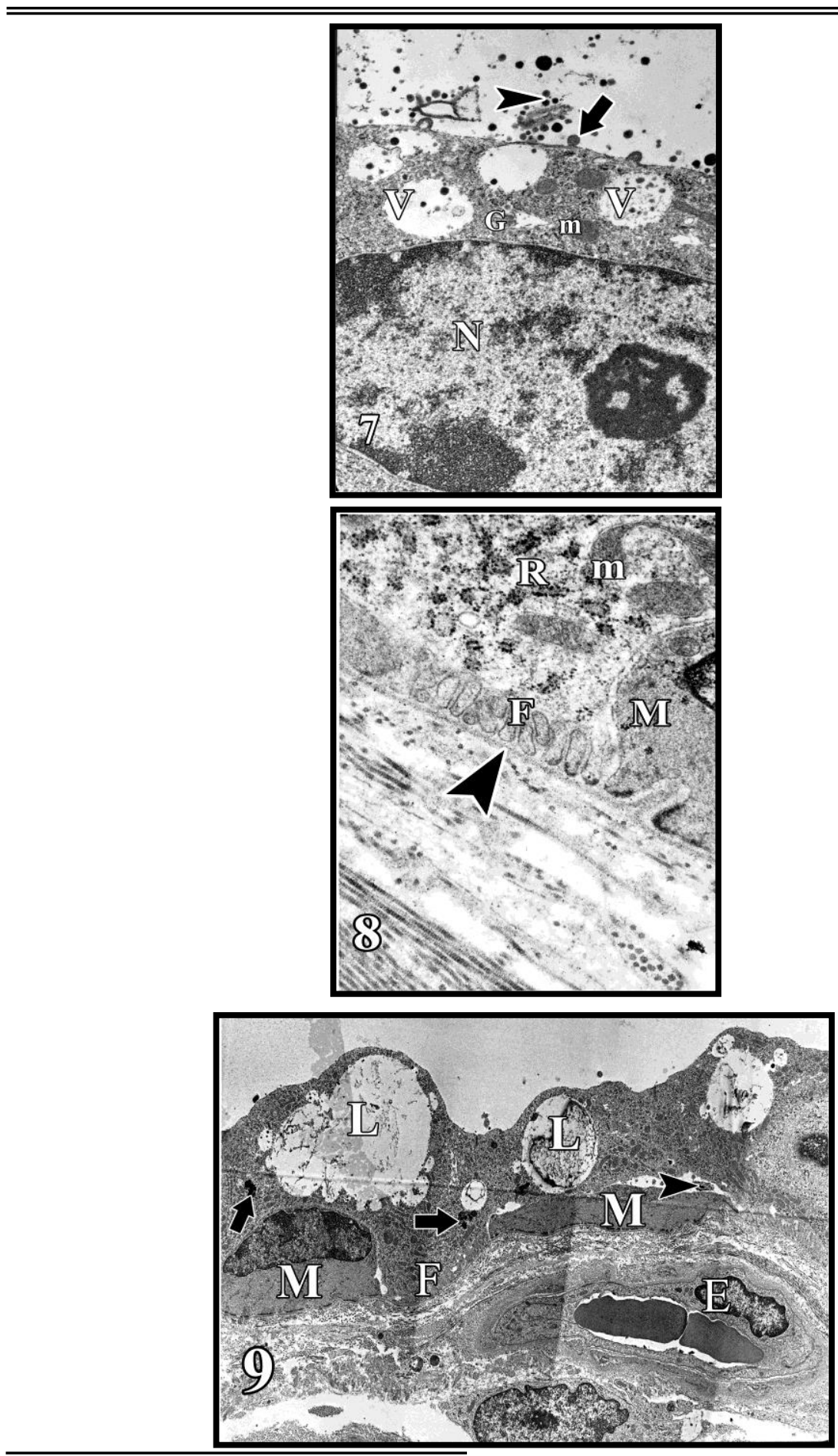

$\overline{\text { Kafrelsheikh Vet. Med. J. Vol. } 5 \text { No. } 2 \text { (2007) }}$ 


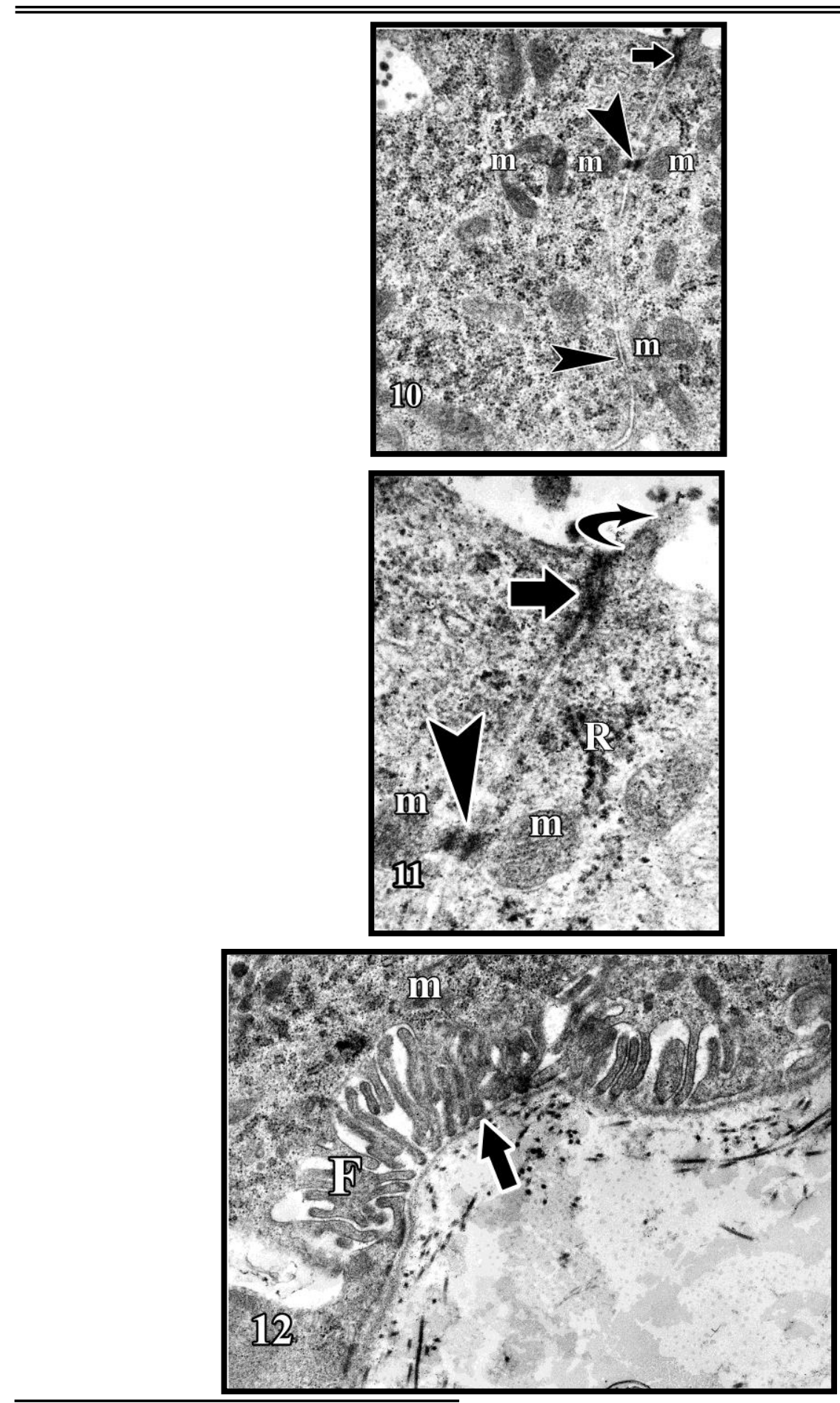

$\overline{\text { Kafrelsheikh Vet. Med. J. Vol. } 5 \text { No. } 2 \text { (2007) }}$ 
El-Habback H. A.

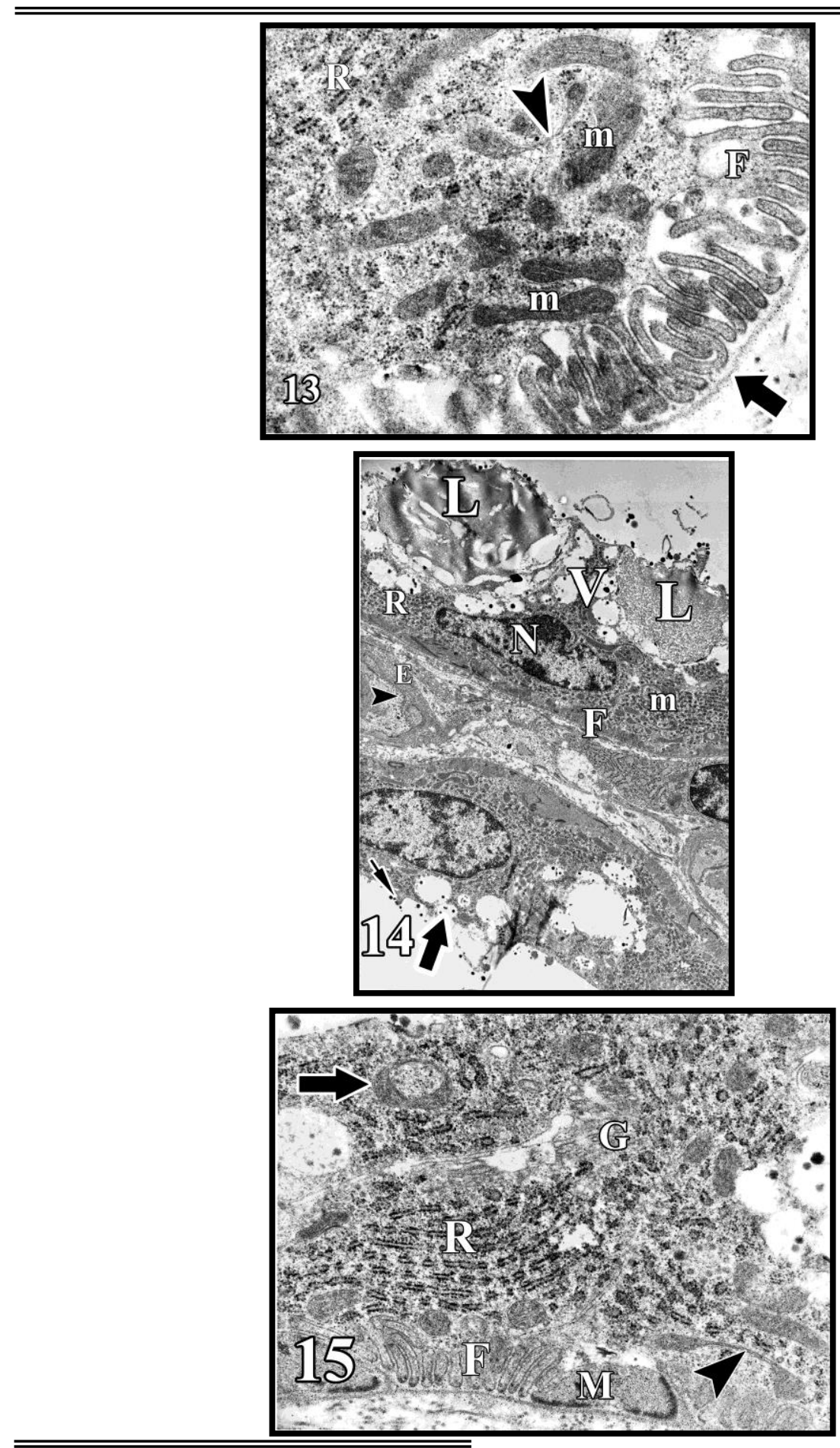

$\overline{\text { Kafrelsheikh Vet. Med. J. Vol. } 5 \text { No. } 2 \text { (2007) }}$ 


\section{REFERENCES}

- Abdurahman, O. A. S. (2006). Udder health and milk quality among camels in the Errer valley of eastern Ethiopia. Development 18(8).

- Abdurahman, O. S., Cooray, R. \& Bornstein S. (1992). The Ultrastructure of Cells and Cell Fragments in Mammary Secretions of Camelus bactrianus, Journal of veterinary medicine A 39, 648-655.

- Adamiker, D. \& Glawischnig, E. (1967a). Elektronenmikroskopische Untersuchungenander Schweinemilchdriise. Teil I. Befunde an Drusen virgineller, gravider und laktierender Tiere. Wiener tierdrztliche Monatsschrift 54, 507-518.

- Adamiker, D. \& Glawischnig, E. (1967b). Elektronenmikroskopische Untersuchungenander Schweinemilchdruse. Teil II. Diskussion der Befunde. Wiener tierdrztliche Monatsschrift 54, 575-583.

- Baker, E. N., Baker, H. M. \& Kidd, R. D. (2002). Lactoferrin and transferrin: Functional variations on a common structural framework Biochem. Cell Biol. 80(1): 27-34.

- Bargmann, W. \& Knoop, A. (1959). Uber die Morphologie der Milchsekretion. Licht- und elekronen mikroskopische Studien an der Milchdriise der Ratte. Zeitschrift far Zellforschung und mikroskopische Anatomie 49, 344-388.

- Bargmann, W., Fleischhauer, K. \& Knoop, A. (1961). Uber die Morphologie der Milchsekretion.Biochem.Cell Biol.80(1):27-34.

- Bomhard, D. \& Kappes, H. (1976). Ultrastrukturelle und ultrahistochemische Untersuchungen an der Milchdrulse des 
Hundes. I. Ultrastrukturelle Untersuchungen. Zentralblatt far Veterinarmedizin, C 5, 68-78.

- Bousquet, M. O. (2002). Milk lipid and protein traffic in mammary epithelial cells: joint and independent pathways. Reprod. Nutr. Dev. 42, 149-162.

- Brooker BE. (1983). Pseudopod formation and phagocytosis of milk components by epithelial cells of the bovine mammary gland. Cell Tissue Res. 229(3), 639-50

- Brooker,B. E. (1984). An ultrastructural study of the sinus epithelium in the mammary gland of the lactating ewe. J. Anat. 138 (2), 287-296.

- Cowie, A. T. \& Tindal, J. S. (1971). The Physiology of Lactation. London: Edward Arnold.

- Deane, H. W., Wurzelmann, S. \& Kostellow, A. B. (1966). Survey for mitochondrial desmosome complexes in differentiating epithelia. Z. Zellforsch. mikrosk. Anat. 75, 166177.

- Dylewski, D. P., Haralick, R. M. \& Keenan, T. W. (1984). Three-dimensional ultrastructure of the Golgi apparatus in bovine mammary epithelial cells during lactation. J. Ultrastructure Res., 87 (1), 75-85.

- El-Kholy (1994). Postnatal development of mammary gland of she- camel (Camelus dromedaries). P.HD. thesis, Facult. Of Vet. Med., Alex. University. Experientia 26, 1345-1347.

- Feldmann, J. D. (1961). Fine structure of the cow's udder during gestation and lactation. Laboratory Investigation 10, 238-255.

- Franke, W. W. \& Keenan, T. W. (1979). Mitosis in milk 
secreting epithelial cells of mammary gland: an ultrastructural study. Differentiation. 13(2), 81-88.

- Goldman, R. D. (1971). The role of three cytoplasmic fibers in BHK-21 cell motility. J. Cell Biol. 51, 752-762.

- Gros, C. \& Girardie, J. (1970). Ultrastructure de la glande mammaire humaine non cancereuse. Experientia 26, 13451347.

- Guidry, A. J., O'Brien, C. N. \& Douglass, L. W. (1998). A bovine mammary endothelial/epithelial cell culture model of the blood/milk barrier. Can J. Vet. Res. 62(2),117-21.

- Hayat,N.A.,(1989). Principles and techniques of electron microscopy, biological application 3 rd Ed., Aspen publisher Inc. Rockville, Maryland.

- Helminen, H. J. \& Ericsson, J. L. (1968). Studies on mammary gland involution (I. On the ultrastructure of the lactating mammary gland.) Journal of Ultrastructure Research 63, 316-322.

- Hollmann, K. L. (1959). L'ultrastructure de la glande mammaire normale de la souris en lactation. Etude en microscope electronique. Journal of Ultrastructure Research 2, 423-443.

- Kappeler, S., Farah, Z., \& Puhan, Z. (1999). Alternative Splicing of Lactophorin mRNA from Lactating Mammary Gland of the Camel (Camelus dromedarius). Journal of Dairy Science 82 (10), 2084-2093.

- Lee, C. S., Morgan, G. \& Wooding, F. B. P. (1979). Mitochondria and mitochondria tonofilament- desmosomal associations in the mammary gland secretory epithelium of 
lactating cows. J. Cell Sci. 38, 125-135.

- Ludewig, T. (1996). [Light and electron microscopic investigations of the blood-milk barrier in lactating cow udders]. Anat. Histol. Embryol. 25(2):121-126.

- Moussa, M. H., Shahin, Y., Kandil, M. \& El-Skhawy, M. (1981). The contractile tissue in the mammary gland of the one humped she- camel (Camelus dromedaries). Egypt. J. Histol. 4 (1), 59-63.

- Murad, T. M. \& v. Haam, E. (1968). Ultrastructure of myoepithelial cells in human mammary gland tumours. Cancer 21, 1137-1149.

- Nickerson, S. C., Akers, R. M. \& Weinland, B. T.(1982). Cytoplasmic organization and quantitation of microtubules in bovine mammary epithelial cells during lactation and involution. Cell Tissue Res., 223(2),421-430.

- Parmely, M. J. \& Beer, A. E. (1977). Colostral cell-mediated immunity and the concept of a common secretory immune system. J. of Dairy Science, 60, 655-665.

- Pitelka, D. R. (1978). Cell contacts in the mammary gland. In Lactation: A Comprehensive Treatise, vol. 4 (ed. B. L. Larson), pp. 41-66. New York: Academic Press.

- Pulley, L. T. (1973). Ultrastructural and histochemical demonstration of myoepithelium in the normal canine mammary gland. American Journal of Veterinary Research 34, 1505-1512.

- Radnor, C. J. (1972). Myoepithelium in the prelactating and lactating mammary glands of the rat. Journal of Anatomy 112, 337-353.

- Seelig, L. L. \& Beer, A. E. (1978). Transepithelial migration of 
leukocytes in the mammary gland of lactating rats. Biology of Reproduction 17, 736-744.

- Sekhri, K. K. \& Faulkin, L. J. (1970). Mammary gland. In The Beagle (ed. A. C. Anderson), pp. 327-349. Ames: Iowa State University Press.

- Sinowat,, S., Worbel, K., El Etreby, M. \& Sinowatz, F. (1980). On the ultrastructure of the canine mammary gland during pregnancy and lactation. J. Anat., 131 (2), 321-332.

- Stirling, J. \& Chandler, J. (1976). The fine structure of the normal, resting terminal ductal-lobular unit of the female breast. Virchows Archiv far pathologische Anatomie und Histologie 372, 205-226.

- Toker, C. (1967). Observations on the ultrastructure of a mammary ductule. J. of Ultrastructure Research 21, 9-25.

- Waugh, D. \& Van Der Hoeven, E. (1962). Fine structure of the human female breast. Laboratory Investigation 11, 220-228.

- Welsch, U., Feuerhake, F., van Aarde, R., Buchheim, W. \& Patton, S. (1998). Histo- and cytophysiology of the lactating mammary gland of the African elephant (Loxodonta africana). Cell Tissue Res., 294 (3): 485-501.

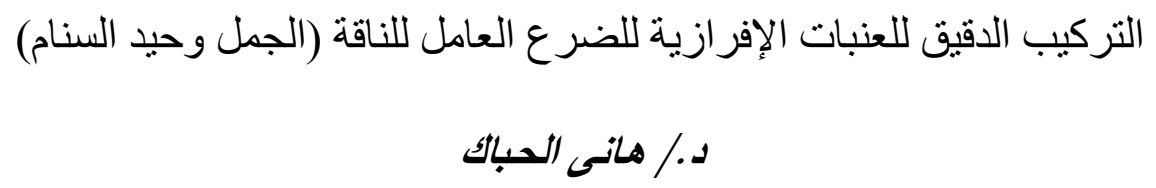

قسم الظلية و الأنسجة- كلية الطب البيطرى- جامعة القاهرة 
أجريت الدراسة على الوحدات الإفرازية لضرع النوق أثناء فترة الحليب. تتوعت الخلايا الإفرازية

إلى أربعة أنواع و أظهرت تللك الخلايا تغيرات واضحة فى الإرتفاع و الثكل و توضع الأنوية و كذلك تطور نمو العضيوات فيها أثناء فترة الحليب.

كان من أهم الخصائص التركيبية نثىى الغشاء القاعدى لظهارة الخلايا الإفرازية و ترتيب الميتوكوندريا معطية لذلك النمط النموذجى للخلايا الناقلة للأيونات. نوقتت العلاقة بين التركيب الدقيق للخلايا و القيمة الغذائية لحليب الناقة و كذلك طريقة افراز الدهون و البروتينات فى الخلايا الإفرازية للضرع. 